THURSDAY, MARCH I, I883

\section{RECENT ARMOUR-PLATE EXPERIMENTS}

$\mathrm{A}^{\mathrm{T}}$ the conclusion of their labours the "Iron Plate A Committee" reported, in 1865 , that the best material for the armour of war-ships was wrought iron of the softest and toughest nature. Steel, or steely iron, or combinations of iron and steel were all pronounced unsuitable for the purpose, after a long course of careful experiments. Accepting this verdict the designers of armoured ships continued to specify for soft iron armour, the makers of guns and projectiles aimed at the perforation of this kind of armour, and the manufacturers sought to secure the desired qualities of softness and toughness in the thicker and heavier plates which they were constantly being called upon to produce. All the armoured ships built from 1860 to 1876 were "ironclads," and in that time the thicknesses of armour plates carried on the sides or batteries of completed ships had advanced from $4 \frac{1}{2}$ inches to 14 inches, while the weights had risen from 4 or 5 tons to 20 or 25 tons. Greater aggregate thicknesses of iron had been arranged for prior to 1876 . For example, the Inflexible had been designed to carry 24 inches of iron on her sides, but this was in two layers of I 2 -inch plates. The adoption of the so-called "sandwichfashion " of armour plating was based upon experiments made at Shoeburyness, and it had certain advantages of a constructive character; it also enabled broader and longer plates to be produced within the fixed limits of weights with which the manufacturers could deal, and enabled them to insure excellence of quality which might not have been so certain of attainment in plates of 20 inches or upwards in thickness.

While the two great Sheffield firms and their rivals in France were thus developing the manufacture of iron armour plating, the Creusot Company, of which M. Schneider was the head, were attempting to reverse the verdict against steel armour, and to produce specimens which could hold their own against the best iron armour of equal thickness. The Italian Admiralty brought the claims of the rival materials to the test of experiment at Spezia in October, 1876 . In order to decide on the kind of armour to be used on the Duilio and Dandolo, specimen targets were erected and a series of firing trials made against them on a scale of unprecedented magnitude. A gun weighing 100 tons, manufactured at Elswick, was brought to beak upon targets protected by iron or steel plates 22 inches thick, backed by great masses of timber and strong supports. Other guns of considerable weight and power were also used, but their performances were overshadowed by those of the monster weapon. The results of these trials may be briefly summarised. Against the ro-inch and II-inch guns the 22-inch iron plates had a decided advantage over the steel plate of equal thickness. The penetration was somewhat greater in the iron plates, but the steel plate cracked badly. On the other hand, when the roo-ton gun was brought against the targets the iron plates and their backings were completely perforated as well as broken up : whereas the steel plate, although smashed to pieces, prevented the shot from passing through the backing. Various opinions were VOL. XXVII.-No. 696 formed as to the deductions which should be made from these trials. On the one side it was urged that as steel plates of great thickness could be gradually cracked and destroyed by guns incapable of perforating them, steel ought not to be used instead of iron, which could be battered by a great number of projectiles from such guns, and be neither perforated nor cracked. On the other side it was maintained that there was small probability of any single armour plate on a ship's side being struck repeatedly in action ; and consequently that the material should be preferred which could best resist perforation by a single projectile from the most powerful gun, even if the resistance to perforation involved the partial destruction of the plate struck. The Italian authorities adopted the latter view, and the Duilio and Dandolo have steel armour, being the first ships protected in that manner.

Although these steel armour plates were made in France, the French authorities did not follow the Italian lead and abandon iron armour. Nor was a similar course followed in England. Change was seen to be inevitable, but it was endeavoured to make the change in a direction which should combine the high resistance to perforation of steel with the power to resist cracking and disintegration possessed by tough rolled iron. To Messrs. Cammell and Co. of Sheffield belongs the honour of taking the lead in this direction; Messrs. Brown speedily followed, and the Admiralty gave substantial assistance in the conduct of the necessary experiments. In the earlier stages many failures and disappointments were experienced ; but eventually better results were obtained, and "steel-faced armour" became recognised as the substitute for iron on English war-ships. Steel-faced armour, as the name implies, consists of a rolled iron back-plate, on the face of which is welded a layer of steel. The hard steel face resists perforation, and breaks up or deforms the projectiles, while the intimate union of the tough iron back with the hard steel face prevents the serious cracking which occurs in steel alone. Curiously enough the idea was not merely an old one, but a small plate made on this principle, $4 \frac{1}{2}$ inches thick, had been fired at in 1863 . This early steel-faced plate was broken into two pieces at the first shot of a light gun, and was condemned by the Iron Plate Committee. Fourteen years later plates of a similar character, so far as the combination of steel and iron is concerned, but of improved manufacture, were successfully resisting three shots, either of which would have perforated an iron plate of equal thickness.

The first steel-faced plates were used on the Inflexible's turrets: they were 9 inches thick, worked "sandwichfashion" outside 7 -inch iron armour. It was part of the contract that a test-piece from each steel-faced plate should be fired at with a I2-ton gun, and should receive three shots without being broken up or perforated. This was considered to be a very severe test at the time, and undoubtedly was so when the novel conditions of the manufacture are considered. It was successfully met, however, and from that time onwards the manufacture has steadily improved. As an indication of what has been done, it may be stated that steel-faced plates in inches thick have received no less than eight shots from the I2-ton and I8-ton muzzle-loading guns, with battering charges and at Io yards' range, without perforation or 
very serious cracking, this enormous "punishment" having been sustained by an area of 48 square feet only. Most of the trials made against steel-faced armour have been against plates from 10 to 12 inches in thickness. For thicknesses up to 12 inches it is probably within the truth to say that for normal impact the steel-faced plates of recent manufacture have been equal in their resistance to perforation to iron plates 25 to 30 per cent. thicker and heavier. For oblique impact the hard armour is probably still more superior to iron, glancing the projectiles at angles of obliquity when they would have "bitten" into the iron. A few experiments have been made in this country and abroad on much thicker steel-faced plates, ranging up to 18 or 19 inches in thickness, and of these the most recent and important are the trials made at Spezia in November, 1882. Three targets were constructed for these trials, the armour plate on each being nearly i I feet long, $8 \frac{1}{2}$ feet wide, and I 9 inches thick. One of the targets was covered by a steel-faced plate made by Messrs. Cammell, another by a steel-faced plate made by Messrs. Brown, and the third by a steel plate made at Creusot. All three plates were similarly backed and supported by 4 feet of oak; the Creusot plate was fastened by no less than 20 bolts, and the Sheffield plates had only 6 bolts each. Against these targets the roo-ton muzzleloading gun was brought into action. At first the powdercharge used (329 lbs.) was that which gave such a velocity to the chilled cast-iron projectiles-2000 lbs. in weight-as would have perforated a 19-inch iron armour plate. The actual penetrations were from $3 \frac{1}{2}$ to 5 inches in the steel-faced plates, and $8 \frac{1}{4}$ inches in the steel plate, showing that the actual superiority of all the plates over iron considerably exceeded the estimate. The steel plate did not crack at the first shot: the steel-faced plates did, but not to any serious extent. Next followed a more severe attack, the powder charge being increased to 480 lbs., giving the projectiles a velocity estimated to be capable of perforating about 24 inches of iron armour. The total energy of the projectile moving at this velocity exceeded 33,00 foot-tons. All the plates were broken into pieces by this terrific blow. The steel plate was split into six pieces, but the numerous bolts held these pieces in position, and still preserved the defensive power of the target. Each of the steel-faced plates was broken into five pieces, and on account of the fewness of the bolts these pieces fell to the ground, leaving the targets uncovered. The whole of the chilled cast-iron shots were broken up on impact, and the penetration into the steel-faced plates was less than that in the steel plate. At this stage the comparative tests ended. A third round was fired, with the heavier charge and a steel projectile against the steel plate. The shot was stopped, the penetration was only 7 inches, but the plate was broken up, and the backing seriously splintered. A fourth round was fired at this target and completely wrecked it.

On a review of all the circumstances of the experiments, it must be admitted that the greatest success was attained by the steel plate, although this must be attributed rather to the number and excellence of its fastenings than to superiority in quality of the plate over the steel-faced plates. The latter proved themselves less penetrable than the steel plate, and had rather the advantage as regards fracture at the end of the first two series of rounds; but they were insufficiently secured. One definite lesson to be learned from these experiments is, therefore, that a larger number of bolts is needed for a given area of steel or steel-faced armour than has been commonly used. Another lesson taught by these trials is that the steel armour plates of Creusot manufacture in I 882 are far superior to those made six years earlier. It is not at all probable that light guns such as broke the 22-inch steel plate to pieces in 1876 would have been equally effective against the 19 -inch plate recently tested. In both cases the plates were made specially for the firing tests, and they may not have been "merchantable articles" in the sense of representing large quantities of steel armour. But nevertheless this ig-inch plate shows what can be done with steel, if cost is of secondary importance. Authoritative statements are wanting of the actual processes of manufacture, or of the cost of production. It is reported that the 19 -inch plate was hammered down from an ingot three or four times as thick as the finished plate, and that the face was oil tempered. If this is correct the cost must be high, and probably as great as, if not greater than, that of steel-faced plates. Moreover if such an amount of "work" has to be put into steel plates in their conversion from ingots into the finished forms, then no great economy or advantage can result from the power which the maker has to cast steel ingots in special shapes or sectional forms. The Creusot Company use a soft steel containing perhaps three-tenths to four-tenths per cent. of carbon, give it toughness by means of a large amount of hammering, and harden the face by oil tempering. On the contrary, the Sheffield firms, as the result of numerous experiments, use a hard steel for the face, the percentage of carbon amounting to about twice that in the Creusot plate, and support this by a tough iron back. With this hard steel, oil tempering does not appear to be beneficial, although with softer steel it undoubtedly is an advantage. These steel-faced plates which were tested at Spezia were really samples of large quantities made at Sheffield in the same manner. Probably equally good results would have been obtained if any one of the batch of plates represented had been selected for test. In this respect, therefore, there is a marked difference between the test to which the two manufactures were subjected.

As between the steel and steel-faced plates tried at Spezia we may assume that there is no notable difference in resistance to perforation or to fracture. Possibly, with equally good and equally numerous fastenings the steelfaced plates would have had some slight advantage, and in other trials mentioned later on steel-faced plates have had a decided advantage. Supposing no important difference to exist, then the choice between two kinds of armour will be governed by their relative prices; and how these compare, we have no means of judging, but it seems probable that the steel-faced plates would be at least as cheap as steel plates made in the manner described above for the steel test-plate.

It may be convenient in this connection to briefly describe the mode of manufacture of steel-faced plates. Messrs. Cammell prefer to pour the molten steel on to the face of a wrought-iron plate which has been brought to a good welding heat. The layer of molten steel is surrounded by a frame of wrought-iron which has 
previously been attached to the iron plate; and it is pressed against the surface of the iron plate by a cover carried by an hydraulic ram, until the welding is complete and the steel has solidified. Messrs. Brown prefer first to roll a steel face-plate as well as an iron back-plate, and then to raise both to a welding heat; the molten steel is afterwards poured into a space left between the two, and hydraulic pressure is applied until the solidification has taken place. The remaining processes are similar in the practice of both firms. After welding has been completed, the whole mass is reheated and rolled down to the finished thickness of the armour plate. The steel face is usually about one-half the thickness of the iron back, and it is a curious fact that the iron and steel maintain their relative thicknesses as the rolling proceeds, even when the reduction in thickness during rolling is very considerable. This reduction varies from one-half for thin armour-plates, up to Io or I inches in finished thickness, to one-third with 18 to 20 inches of finished thickness. Some competent authorities consider that too little work is done in the rolls on the thicker plates, but there is a need for further experiment to show whether this view is correct. Whatever may be the cause, it would seem that the best results so far have been obtained with steel-faced plates below 12 inches in thickness.

Simultaneously with the Spezia experiments another competition was proceeding, near St. Petersburg, between steel-faced and steel armour. The plates tested were I2 inches thick, 8 feet long, and 7 feet wide. They were first fired at with the II-inch breech-loading gun, throwing a $550-\mathrm{lb}$. chilled cast-iron projectile, with a powder charge of 132 lbs. The velocity of the shot was 1500 feet per second. Messrs. Schneider supplied the steel plate, which was fastened with twelve bolts. Messrs. Cammell made the steel-faced plate, which had only four bolts in it. The first blow on the steel plate broke it into five pieces; the projectile was destroyed, but it penetrated 13 inches into the target. A blow of equal energy on the steel-faced plate produced only a few unimportant cracks in the steel, and the penetration was about 5 inches only. Three out of the four bolts were, however, broken. A second shot was then fired at each plate with $8 \mathrm{I}$ lbs. charge. The steel plate was broken into nine pieces, and the penetration was 16 inches: whereas on the steel-faced plate the principal effect produced was to break the only remaining bolt and to let the plate fall to the ground, face downwards. The back of this plate was perfect, and the target behind the plate was uninjured. In this trial the steel-faced plate proved greatly superior to the steel, but had insufficient fastenings. It is proposed to increase the bolts in number, re-erect the plate, and continue the trial, of which the further results cannot fail to be interesting.

This contest between steel and steel-faced armour must not be allowed to withdraw attention from the great superiority of both, in certain respects, to iron armour. Even as matters stand, either of these modern defences is greatly to be preferred to their predecessor. Against this hard armour chilled cast-iron projectiles break up in a manner never seen with soft iron. Projectiles of this kind are virtually impotent, and must be replaced by more expensive, harder projectiles, if steel or steel-faced armour is to be attacked. Even with steel projectiles results cannot be obtained such as were possible with iron armour. Perforation of armour by shells carrying relatively large bursting charges is no longer a possibility : and the heaviest gun yet made cannot drive its projectiles through a thickness of hard armour only three-fourths as great as the thickness of iron which it it could perforate.

The use of steel and steel-faced armour will involve many experiments to determine not merely what descriptions of projectiles are best adapted to damage or penetrate it, but what are the laws of the resistance of such armour to penetration and disintegration. All the formulæ based on experiments with soft iron armour and chilled cast-iron projectiles are inapplicable under the new conditions. Perforation is no longer to be feared as the most serious damage likely to happen to armour plates: more moderate thicknesses of hard armour suffice to stop the projectiles from the heaviest guns than would have been considered possible a short time ago. Instead of perforating 19 inches of steel or steel-faced armour, the projectile of the Ioo-ton gun with a given velocity only penetrates 8 inches into the plates. But, on the other hand, the possible disintegration and fracture of the armour plates are becoming important matters. Makers of armour plates have to endeavour to produce materials which shall resist fracture as well as penetration, and the only proof of their success or failure is to be found in the results of actual trials. Experiments are equally essential to progress in the manufacture of guns and projectiles. The example set by Italy must be followed; the necessary experiments must be on a large and costly scale, and they may lead to many departures from former practice. But if real progress is to be made in the armour and armament of ships, it must be prefaced by experiments beside which those of the former Iron Plate Committee will appear insignificant.

In conclusion it may be stated that although iron armour has been practically superseded for the sides and batteries of war ships, it is still preferred for decks. Experiments have shown that for angles of incidence below 20 degrees, and for such thicknesses-not exceeding 3 or 4 inches -as are used on decks, good wrought-iron is superior to both steel and steel-faced plating. The explanation of this departure from the laws which hold good for thicker plates and greater angles of incidence cannot be given here, but the fact has been established by elaborate trials made in this country and abroad.

\section{SMOKE ABATEMENT}

Report of the Committee of the Smoke Abatement Exhibition. (London: Smith \& Elder, 1883.)

THIS volume, which has just been issued, presents 1 many points of interest, as it is the outcome of the labours of a Committee formed in $188 \mathrm{I}$ with a view to ascertain what means could be adopted to check the growing evils arising from the evolution of smoke which attends the combustion of bituminous coal. It may be said to be the continuation of work undertaken by the several Parliamentary Committees which met in 1819, 1843, and in 1845 . In the previous efforts attention appears to have been mainly directed to lessening the 